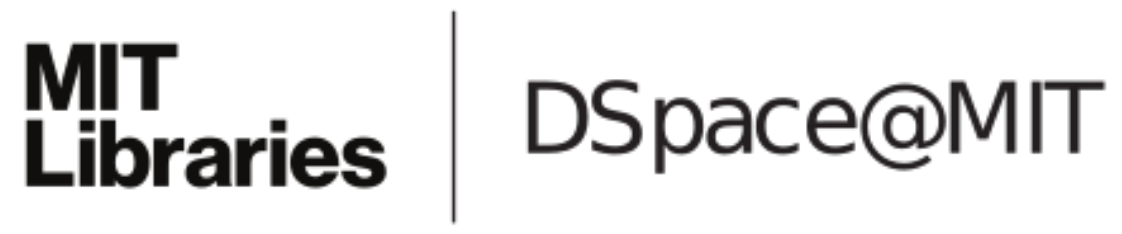

MIT Open Access Articles

Is This Time Different? Capture and Anti-Capture of US Politics

The MIT Faculty has made this article openly available. Please share how this access benefits you. Your story matters.

Citation: Acemoglu, Daron, and James A. Robinson. "Is This Time Different? Capture and AntiCapture of US Politics." The Economists Voice 9, no. 3 (January 27, 2012). () De Gruyter

As Published: http://dx.doi.org/10.1515/1553-3832.1902

Publisher: Walter de Gruyter

Persistent URL: http://hdl.handle.net/1721.1/80330

Version: Final published version: final published article, as it appeared in a journal, conference proceedings, or other formally published context

Terms of Use: Article is made available in accordance with the publisher's policy and may be subject to US copyright law. Please refer to the publisher's site for terms of use. 


\section{Is This Time Different? Capture and Anti-Capture of U.S. Politics ${ }^{1}$}

\section{DARON ACEMOGLU AND JAMES A. ROBINSON}

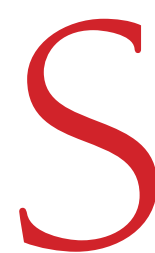
ocieties are molded by their institutions that determine both their levels of prosperity and how that prosperity is distributed within society. For most of its history the U.S. has had economic institutions which have been comparatively inclusive in the sense that economic opportunities have been open to most, the playing field has been level, and property rights have been secure. The inclusiveness of economic institutions has

James Robinson is David Florence Professor of Government at Harvard University. His research interests are in comparative economic and political development. He is currently conducting research in the Democratic Republic of the Congo, Sierra Leone, Haiti and in Colombia where he teaches at the University of the Andes in Bogotá.

Daron Acemoglu is the Killian Professor of Economics at MIT. In 2005 he received the John Bates Clark Medal awarded to economists under forty judged to have made the most significant contribution to economic thought and knowledge.

DOI: $10.1515 / 1553-3832.1902$

() De Gruyter meant that the U.S. has been fully able to harness the talent of its citizens who have consequently experienced high rates of social mobility.

Obviously economic institutions were not inclusive everywhere in the U.S. The federal system allowed for institutional divergence and the Southern states had much more extractive institutions, with a tilted playing field in favor of elites and weak or absent property rights for many in society. Instead of opening economic institutions to everyone or allowing social mobility, extractive institutions restrict opportunities to a powerful few and block social mobility. The children of slaves were also slaves, slaves could not own property, had no opportunity for social mobility or the free choice of occupations or careers and it was even illegal to teach slaves to read and write in most Southern states prior to the Civil War (Margo 1991).
The roots of inclusive economic institutions in the U.S. lie in a long history of conflict and struggle. Going right back to the founding of the Jamestown colony in 1607 the Virginia Company wanted to create an extractive society especially after it realized it could not make money by exploiting indigenous peoples (too thin on the ground) or precious minerals (there were none). So instead it propagated its "Lawes Divine, Morall and Martiall" where private property was all but abolished and the settlers were forced into barracks and a draconian work regime. It did not work. The settlers ran away to the frontier and they began to organize to demand different institutions. This process culminated in the creation of the "headright system" in 1618 giving settlers access to land. Aspiring oligarchs tried again in Maryland, Pennsylvania and the Carolinas. For example, the Fundamen- 
tal Constitutions of Carolina laid out a rigid social structure with "leet-men" at the bottom with clause 23 noting: "All the children of leet-men shall be leet-men, and so to all generations." Not quite what Ronald Reagan had in mind when he talked in his farewell address about the "shining city on a hill."

Inclusive economic institutions were underpinned by inclusive political institutions. At the same time as the settlers in Jamestown won the headright system they gained/obtained self-government in the form of a Legislative Assembly which effectively enfranchised all adult white males. The Virginia Company had been unable to exploit the white settlers because in the New World the de facto distribution of political power was very broad, the creation of the Assembly institutionalized this inclusive distribution of political power. The inclusive political and economic institutions which developed in the colonial period continued into the nineteenth century. Even though the constitution disenfranchised women and blacks, by the 1820s all Northern states had universal white male suffrage and this spread to the South by 1850 . Political rights were broadly distributed by world standards and it was this even distribution of political power that forced open economic institutions, breaking down monopolies (e.g., in banking, Haber 2010) and opening up the frontier to allow land to be equally distributed, as demonstrated by García-Jimeno and Robinson (2011) (see Keyssar 2009, for an overview).

The consequences of these inclusive institutions were that the U.S. became one of the most prosperous and technologically dynamic societies in the world (Sokoloff and Kahn 1990, on how non-elites were crucial for innovation). Not only was the U.S. prosperous it was egalitarian. The distribution of assets, income and opportunity generated by inclusive economic institutions was relatively equal.

Once created there is a natural tendency for inclusive institutions to persist - a virtuous circle where inclusive economic institutions spread opportunities, income and wealth more equitably which in turn helps sustain the broad distribution of political power and economic resources. Nevertheless, the system faced continual challenges, most obviously from the Southern states until the Civil War and the rapid economic success of the second half of the nineteenth century created fresh challenges. Though inclusive institutions might gener- ate equality and economic progress, some can always benefit by taking institutions in a more extractive direction, by erecting barriers to entry and excluding people from profitable economic opportunities to create monopoly, and by undermining the property rights of others to defend and use their assets.

The economic growth of the second half of the nineteenth century, the Gilded Age, created a group of very wealthy new businessmen, the "Robber Barons." One of the most notorious was Cornelius Vanderbilt who remarked: "What do I care about the Law? Hain't I got the power?" (quoted in Josephson 1934, p. 15). Another was John D. Rockefeller, who started the Standard Oil Company in 1870 which by 1890 controlled 88 percent of the refined oil flows in the U.S. Contemporary cartoons depict Standard Oil as an octopus wrapping itself round not just the oil industry but also Capitol Hill.

The positioning of the tentacles of the octopus is significant. The wealth of the Robber Barons was created by their ability to take advantage of many new economic opportunities that emerged, often generated by new technologies like railroads. These men also quickly became adept at using this wealth to manipulate the po- 
litical system to their advantage. Crucially, the Robber Barons captured the Senate, which was indirectly elected by state legislatures and they narrowed the distribution of political power. This process was satirized by the journalist David Graham Phillips in a series of articles under the rubric of the "Treason of the Senate" in the Cosmopolitan magazine starting in March 1906 (collected in Phillips 1953). Philips went state by state. First was New York Senator, Chauncey Depew, long a lawyer for the Vanderbilt family and their chief lobbyist in Albany for which he was eventually rewarded with a seat in the Senate. Phillips then moved to Rhode Island where the chief villain was Nelson Aldrich, none other than Rockefeller's son-in-law. Here he described not just how Aldrich played the same role for Rockefeller as Depew did for Vanderbilt, but also how the political institutions allowed this to happen, how "The apportionment of legislators is such that one-eleventh of the population ... elect a majority of the legislature - which means they elect the two United States senators.. The Aldrich machine controls the legislature, the election boards, the courts - the entire machinery of the "republican form of government"."The increasingly extractive nature of political institu- tions allowed the Robber Barons to threaten the inclusive economic institutions which had made the U.S. so prosperous.

But the institutional equilibrium was more robust than it first appeared. The Gilded Age created a backlash in society in the form of the Populist and then subsequently the Progressive movements. The Populist movement emerged out of a long-running agrarian crisis, which afflicted the Midwest from the late 1860s onward (Sanders 1999). By 1892 rural interests had formed a coalition with organized labor and created the People's Party. At the founding of the party in Omaha, Nebraska they adopted the Omaha Platform, demanding specific policy changes, such as the introduction of an income tax, which until then had been deemed unconstitutional. More important it demanded a series of reforms in political institutions intended to undermine the aim of the political parties to "secure corruption funds from the millionaires." These included direct elections for senators, the introductions of ballot initiatives and referenda which they thought would improve democratic accountability.

These political movements slowly began to have an impact on political attitudes and then on legislation, particularly concerning the role of the state in the regulation of monopoly. They induced the creation of the Interstate Commerce Act of 1887, which created the Interstate Commerce Commission and initiated the development of the federal regulation of industry and the Sherman Antitrust Act of 1890

Though the Populists seriously declined after they threw their weight behind the Democrats, their reform agenda was taken up by the Progressives, a heterogeneous reform movement which had a more urban and intellectual base. The Progressive movement initially gelled around the figure of Teddy Roosevelt who became president in 1901. Prior to his rise to national office, Roosevelt had been an uncompromising governor of New York and had worked hard to eliminate political corruption and "machine politics." Roosevelt proposed that Congress establish a federal agency with power to investigate the affairs of the great corporations. By 1902, Roosevelt had used the Sherman Act to break up the Northern Securities Company, affecting the interests of J. P. Morgan, and subsequent suits had been brought against Du Pont, the American Tobacco Company, and the Standard Oil Company. Roosevelt strengthened the 
Interstate Commerce Act with the Hepburn Act of 1906 and his successor, William Taft, prosecuted trusts even more assiduously, the high point of this being the breakup of the Standard Oil Company in 1910. Taft also promoted other important reforms, such as the introduction of a federal income tax, which came with the ratification of the Sixteenth Amendment in 1913.

The grassroots opposition was greatly aided by investigative journalists such as Phillips known as "muckrakers" who exposed the abuses of the Robber Barons. The most famous example being Ira Tarbell's 1904 book History of the Standard Oil Company.

These reforms to preserve the inclusive nature of U.S. political and economic institutions were effective in two ways. First they helped guarantee that the rapid economic growth that the U.S had experienced in the second half of the nineteenth century would be sustained. Second they succeeded in reversing the massive increase in inequality and the concentration of wealth which had built up in the previous half century.

More than a century after the Gilded Age, a new era of great opportunities, this time underpinned by advances in information and commu- nication technology and globalization, has again coincided with a huge increase in economic inequality in the U.S. Part of this inequality is a byproduct of the structural transformation of our economy. For example, the technological developments that have swept the U.S. labor market can account for why the demand for workers with high school degree or less has plummeted. However, they cannot plausibly account for why the top 1 percent of Americans captured almost 25 percent of national income in 2007 , up from 9 percent in 1974. For the 0.1 percent this has gone from 3 percent to 12 percent (Piketty and Saez 2003).

This rapidly increasing inequality is similar to that which emerged in the Gilded Age in the sense that it went along with not only economic growth but also an increasing capture of the political system by the wealthy (Bartel, 2010, Hacker and Pierson 2010). The capture of the political system has been facilitated by several other factors; the reaction of conservative and business groups to the "Great Society" programs of the 1960s and early 1970s and the increased taxes that paid for them; the decline of organized labor as an economic and political force; the rise of television as the main medium via which people get their political information, which made money much more powerful as a tool for determining the outcome of elections. The U.S. political landscape was also changed by the rise of fundamentalist Christians, casting their ballots mainly on the basis of normative issues. The co-optation of such voters by the Republican Party has given it greater freedom to propose economic policies favored by its other constituents, most notably the wealthy. The Democrats, often dragging their feet, have typically followed the money, if not in their rhetoric, in actuality in their policies on many important issues such as redistribution and regulation. The result of this cocktail of changes, greater inequality, greater power for the wealthy at unchanged levels of inequality, and greater political utility of the thing the wealthy had most of - money created a new form of "inequality multiplier": as inequality increased the rich were able to push government regulation and policy in their favor, thus creating even more inequality. Just as in the Gilded Age, this trend threatens the inclusive nature of U.S. economic institutions.

Yet these dynamics have created another backlash from outside the traditional political parties in the form of the Occupy Wall Street 
(OWS) movement. The occupiers style themselves as the 99 percent, those excluded from the 1 percent of the population who have snapped up the economic gains the U.S. economy has generated in the last 30 years. They are protesting about rising inequality, falling social mobility, the decline in the social safety net and the capture of politics by the wealthy, the financial industry and the large corporations. As they put it on their web page they are "fighting back against the corrosive power of major banks and multinational corporations over the democratic process."

The interests underpinning this group are different from those of the Populists and Progressives and so are their political strategies. For example, Progressives did not react to the control of the Senate by occupying the front lawn of "The Breakers" Vanderbilt's plush mansion in Newport, Rhode Island. However, it is not surprising that the specific tactics of OWS differ from those of the Populists and Progressives. If one looks at the evolution of social protests over the past few centuries there is continual change as social movements must alter their strategies in response to changes in the structure of the economy and society, in technology, and in the nature of political institutions. An obvious reason for the form that OWS protests have taken is the successful model of revolt in Egypt. The technology of the media and protests is also radically different. The spread of newspapers and literacy allowed modern mass protests to emerge in the eighteenth century, and we have seen the positive role that newspapers and independent muckrakers played in pushing forward the Progressive agenda. Today the emergence of the internet with Twitter and other social media is similarly important in facilitating the emergence of protest and shaping the form it takes.

Nevertheless, their aim is the same, to roll back the increasing threats to the inclusive nature of economic institutions in the U.S. To do this they recognize, as the Populists and Progressives did, that political institutions must be changed to remove the control of the wealthy over the agendas and policies of the main political parties.

Will they succeed in their aims? Or will it be different this time with the capture of U.S. politics now having become more ingrained and more systematic? Of course it is far too early to know the answer to this but the experience of the Populists and Progressives are interesting not just because they were complaining about the same things as OWS, but also because they were successful. Even if the tactics of and the interests behind OWS are different, lessons can be learned about what might make OWS likely to succeed. First, even if the Populists and Progressives mobilized outside of the traditional political parties, their agendas had an enduring impact on political and economic institutions in the U.S. because they were able to force the traditional political parties to take up many of their reforms. Though they did this partially through threatening the entry of an effective third party, this is probably not a necessary condition for such influence. Ultimately OWS will have to build bridges to sympathetic politicians in the mainstream political parties. From this perspective the statement on the OWS webpage that "we don't need politicians to build a better society" is probably short sighted.

Second, Populists and Progressives were successful because they formed a broad coalition. The Populist Party brought organized labor together with farmers and the Progressives added many middle class groups and intellectuals and were even more successful. OWS is similarly trying to reach out to organized labor,

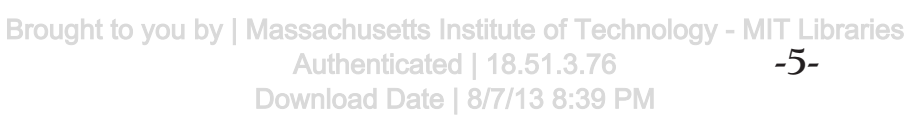

The Economists' Voice http://www.degruyter.com/view/j/ev March, 2012 
to environmentalists and extend into university campuses. It is not the exact details of the coalition that are important but the breadth.

Third, the role of the media will be critical in determining the success of the movement. The role of muckrakers during the Gilded Age notwithstanding, there is no necessity that the media will play a reformist role in society. For example, DellaVigna and Kaplan (2007) identified a "Fox news effect" whereby the spread of the conservative Fox news channel has a significant positive impact on the vote share of Republican candidates. Moreover, as we discussed above, one hypothesis about why U.S. politics has been increasingly captured by money is precisely the increased importance of television since the 1970s as a source of political information. It is not just the existence of media that matters but who owns it and what it is trying to achieve. In the light of this the use of the internet, owned by nobody, is probably critical.

Finally, the lesson from the Populists and the Progressives is that to succeed OWS must come up with a list of specific institutional and policy changes that will help to counterbalance the trends they have set themselves against. These will not be the same as those proposed
100 years ago, but they will be important for focus and for institutionalizing their successes. A cautionary tale here comes from the French student protests and occupations of May 1968 (Tarrow 1993). These were initially quite successful in putting politicians on the defensive in their demands for educational and social change. But the French students did not come up with specific proposals about how, for example, the educational system should change. The government responded first with large wage increases for trade unions to try to isolate the students and then with a proposed loi d'orientation ultimately an emasculated reform which was very far from what the students could have achieved if they had been more focused on the specifics and how to build a political coalition with insiders to get them. Such policies and reforms should focus on the really first-order issues, particularly how to reform the U.S. political system by making it less likely that the wealthy and other special interests can cement their capture of politics

There is still room for being optimistic that this time it will not be different and that the anti-capture forces will be up to the challenge ahead of them. But this optimism depends fundamentally on the willingness of many citizens not to be complacent and stand up and be counted in defense of inclusive institutions. It is this that makes the OWS movement, despite its many flaws, a hopeful sign of the resilience of our institutions.

Letters commenting on this piece or others may be submitted at http://www.degruyter.com/ view/j/ev?tab=services

\section{NOTES}

1. The concepts and arguments used in this paper borrow heavily from our forthcoming book Acemoglu and Robinson (2012).

\section{REFERENCES AND FURTHER READING}

Acemoglu, Daron and James A. Robinson (2012) "Why Nations Fail: Origins of Power, Prosperity and Poverty," New York, Crown.

Bartels, Larry M. (2010) "Unequal Democracy: The Political Economy of the New Gilded Age," Princeton, NJ, Princeton University Press

DellaVigna, Stefano and Ethan Kaplan (2007)

"The Fox News Effect: Media Bias and Voting," Quarterly Journal of Economics, 122: 1187-1234.

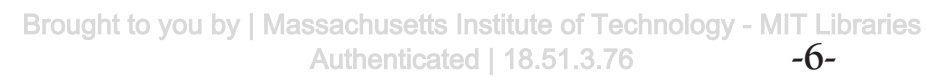


García-Jimeno, Camilo and James A. Robinson (2011) "The Myth of the Frontier," In Dora L. Costa and Naomi R. Lamoreaux, eds, "Understanding Long-Run Economic Growth," Chicago, IL, University of Chicago Press

Haber, Stephen H. (2010) "Politics, Banking, and Economic Development: Evidence from New World Economies," In Jared Diamond and James A. Robinson, eds, "Natural Experiments of History," Cambridge, MA, Belknap Press of Harvard University Press

Hacker, Jacob and Paul Pierson (2010) "Winner Take All Politics: How Washington Made the Rich Richer-and Turned Its Back on the Middle Class," New York, Simon and Schuster

Josephson, Matthew (1934) "The Robber Barons," Orlando, FL, Harcourt.

Keyssar, Alexander (2009) "The Right to Vote: The Contested History of Democracy in the United States," Revised Edition, New York, Basic Books.

Margo, Robert A. (1991) "Race and Schooling in the South, 1880-1950: An Economic History," Chicago, IL,University of Chicago Press.

Phillips, David Graham (1953) "The Treason of the Senate," New York: Monthly Review Press.
Piketty, Thomas and Emmanuel Saez (2003) "Income inequality in the United States, 19131998," Quarterly Journal of Economics, 118: $1-39$.

Sanders, Elizabeth (1999) "Roots of Reform: Farmers, Workers, and the American State, 1877-1917, Chicago, IL, University of Chicago Press.

Sokoloff, Kenneth L. and B. Zorina Khan (1990) "The Democratization of Invention During Early Industrialization: Evidence from the United States, 1790-1846," Journal of Economic History, 50: 363-78.

Tarrow, Sidney (1993) "Social Protest and Policy Reform: May 1968 and the Loi d'Orientation in France," Comparative Political Studies, 25: 579-607.

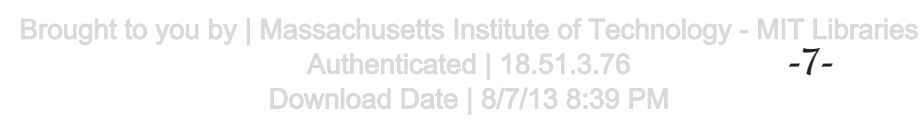

